\title{
THE ROLE OF STATE AND NON-GOVERNMENTAL ORGANIZATIONS IN OVERCOMING CHILD NEGLECT AND HOMELESSNESS
}

\author{
Olga Tepla , Marta Kozak ${ }^{2}$ \\ Lviv Polytechnic National University, Lviv, Ukraine \\ ${ }^{1}$ Student of the bachelor's program "Social Work" of the department of Sociology and Social Work \\ ${ }^{2}$ Ph.D., Associate Professor, of Department of Sociology and Social Work
}

Background: The urgency of the problem of child neglect and homelessness is due to the various cultural, political and socio-economic factors that take place both in Ukraine and in the world at large. Child neglect and homelessness are one of the most pressing problems in today's society. The phenomenon of child neglect and homelessness is complex and ambiguous, as these children find themselves on the streets not only because of the dysfunction of their families, but also because of the indifference of others and society as a whole.

Purpose: Analysis of the theoretical basis and practical aspects of the prevention and overcoming of child neglect and perversion by state and public organizations.

Methods: General scientific theoretical methods are used - analysis of available scientific literature on the problem, synthesis and comparison, comparison of different views on the question under study.

Results: The theoretical principles of prevention and overcoming of child neglect and homelessness by the state and non-governmental organizations are investigated. The main causes of child neglect and homelessness are described. Approaches of preventive activity of state and nongovernmental organization with such children are described.

Conclusion: Preventive work should be focused, continuous, comprehensive. According to the analysis of sources, overcoming child neglect and homelessness is possible only if systematic measures are implemented. Preventive, timely detection and effective provision of social services are important conditions for overcoming child neglect and homelessness. This can be achieved through active cooperation between state and public structures. That is why in the work with street children it is necessary to use qualitatively new forms of work that will allow to solve the problem effectively. Despite the fact that state bodies, public and charitable organizations that care about the problems of street children and homeless children, active work is being done recently to eliminate the causes contributing to the spread of child neglect and homelessness. subjects of prevention of this phenomenon.

Keywords: child neglect and homelessness, causes of child neglect and homelessness, prevention of child neglect and homelessness.

Актуальність проблеми дитячої бездоглядності та безпритульності обумовлена різноманітними культурними, політичними та соціально-економічними чинниками, що мають місце як в Україні, так і у світі загалом. Дитяча бездоглядність і безпритульність одна 3 найболючіших проблем сучасного суспільства. Явище дитячої бездоглядності i безпритульності є складним і неоднозначним, адже ці діти опиняються на вулиці не лише через дисфункцію власних родин, але й внаслідок байдужості оточуючих та суспільства в цілому.

Згідно даних благодійного фонду UWCF в Україні налічується близько 100 тисяч безпритульних дітей. Це діти, що не мають певного місця проживання найчастіше через те, що були покинуті батьками, самостійно залишили сім’ї або дитячі заклади. За даними Державної статистичної служби України кількість дітей, які перебували у центрах соціальнопсихологічної реабілітації протягом року - усього 8387. Причини поміщення дитини в Центри були наступними: потрапили у центри внаслідок: складних життєвих обставин 6032 (71,9\%), залишились поза сімейним оточенням 2110 (25,2\%), переведені з притулків для дітей 134 (1,6\%), жорстокого поводження 111 (1,3\%). («Захист дітей, які потребують особливої уваги суспільства», 2017, с.49). Враховуючи масштабність цього соціального явища вважаємо доцільним проаналізувати стан профілактичної діяльності організацій 
соціального спрямування скерованої на подолання дитячої бездоглядності та безпритульності.

Мета: Аналіз теоретичного підгрунтя та практичних аспектів профілактики та подолання дитячої бездоглядності та б езпритульності державними та громадськими організаціями.

Бездоглядні та безпритульні діти - одна 3 найбільш вразливих категорій населення України. У працях науковців синонімічно можна зустріти термін «діти вулиці», який по-суті відображає основну проблему, а саме перебування дітей поза сімейним оточенням, іноді без чіткого місця проживання. «Діти вулиці» як соціальна проблема характерна не лише для держав, які переживають період трансформації, а й з стабільним економічним розвитком. Терміном «діти вулиці» об'єднують ту категорію дітей, які перебувають на вулиці майже постійно, іноді повністю втрачаючи контакт з рідними.

Аналізуючи причини виникнення бездоглядності як соціального феномену слід звернути увагу на їх різнофакторність. Дослідники цього питання виділяють наступні чинники, що можуть сприяти явищу «дітей вулиці»:

1. Загострення розбіжностей і конфліктів між батьками і дітьми.

2. Ослаблення роботи з організації дозвілля дітей як за місцем їхнього проживання так і навчання.

3. Погіршення матеріального становища значної частини населення України в зв'язку 3 нестабільною економічною ситуацією в державі.

4. Збільшення кількості дітей і підлітків, дозвілля та вільний час яких не організовані належним чином.

5. Перекладання частиною батьків відповідальності за утримання і виховання дітей на державу, освітні заклади.

6. Економічна експлуатація дорослими дитячої праці (залучення до жебракування, крадіжок, махінацій тощо).

7. Негативні тенденції у засобах масової інформації, пропаганда насилля. (Карпенко,2001, Рогач, 2010)

Окрім переліченого в наукових працях наголошується на економічних труднощах в сім’ї, розлученні батьків; асоціальному способі життя одного чи обох батьків; різноманітті форм насилля; ранньому i/aбо позашлюбному материнстві; неповній родині як причинах порушення комунікації всередині сім’і і розвитку явища безпритульності серед дітей (Карпенко,2001; Рогач,2010).

Відомо, що подолання будь якого негативного суспільного явища потребує ефективної профілактики. В Україні до профілактики дитячої бездоглядності та безпритульності залучена ціла низка структур, зокрема такі державні органи як: служби у справах дітей; підрозділи ювенальної превенції, центри соціальних служб для сім'ї дітей та молоді; органи і заклади освіти; органи і заклади охорони здоров'я; притулки для дітей; центри соціальнопсихологічної реабілітації для дітей. Серед профілактичних заходів, які здійснюються працівниками ювенальної превенції, служби у справах дітей разом із фахівцями соціальної роботи, слід виокремити рейди «Вокзал» та «Діти вулиці». У фаховій літературі ці заходи вважаються одними із найефективніших для своєчасного виявлення дітей, які самовільно залишили місце проживання. Однак, i досі не існує законодавчого підгрунтя щодо регламентації проведення вище зазначених профілактичних рейдів.(Горобець, 2011)

Серед профілактичних заходів соціальних служб , на нашу думку, особливо важливим $\epsilon$ своєчасне та ефективне реагування на інформацію про дітей, що є бездоглядними чи безпритульними., вжиття заходів для екстреного втручання за необхідності, сприяння соціальній адаптації дітей, забезпечення умов виховання, наближених до сімейних за не можливості повернути дитину в біологічну сім'ю, здійснення представництва інтересів дитини сприяння їхньому фізичному, духовному та інтелектуальному розвитку. Як форми діяльності соціальних установ і соціальних служб розглядаються заходи, спрямовані на розвиток потенціалу дитини (бесіда, діалог, дискусія тощо). (Макійчук, 2008). 
Вивчаючи питання соціальної роботи з бездоглядними дітьми хочемо наголосити на інших суб'єктах, окрім державних структур. В Україні активною профілактикою дитячої бездоглядності та безпритульності, на наш погляд, займаються громадські організації та благодійні фонди. Одним із них є Благодійний фонд «Карітас - Львів УГКЦ», який активно працює в цьому напрямку, починаючи з 1999 року, зокрема реалізувавши проекти «Кризовий центр «Діти вулиці», «Дошкільний заклад освіти кризовий центр «Діти вулиці», а також «Мобільна робота 3 молоддю в Україні». Вказані проекти спрямовані не лише на фізичний та духовний розвиток дітей, а й на збереження цілісності їхніх сімей, які опинились у складних життєвих обставинах. Важливою складовою діяльності організації є створення середовища довіри для дітей, що допомагає виявити весь комплекс проблем, що виникають у житті дитини. Головний акцент у роботі БФ «Карітас - Львів УГКЦ» ставиться на організації змістовного дозвілля для дітей, формуванні у них позитивного світогляду, сприянні в розвитку особистості дитини та подоланні нею життєвої кризової ситуації. («Інформація про діяльність», 2018)

Розв'язання проблеми бездоглядності та безпритульності серед дітей потребує впровадження цілісної системи соціального захисту їх прав та соціально-психологічної допомоги - від першого контакту на вулиці, до остаточної соціалізації дитини, її адаптації та реабілітації спочатку можливо у притулку (кризовому денному центрі), а потім у сім’і (рідній або фостерній) чи у дитячому будинку сімейного типу. Комплексна модель соціально-педагогічної роботи з бездоглядними дітьми та безпритульними, на думку А. Капської, повинна включати в себе різні рівні, які охоплюватимуть превенцію, своєчасне виявлення, кризове втручання, розвиток замісної опіки. Це зокрема:

- створення майданчиків, клубів дозвілля; телефонів довіри; центрів сімейної психологічної терапії; кабінетів психологічного та юридичного консультування дітей тобто заходів з попередження бездоглядності дітей;

- соціальну роботу на вулиці для виявлення та встановлення контакту з дитиною і їі залучення до роботи із соціальними службами;

- заходів, щзодо влаштування виявлених дітей, зокрема створення денних кризових центрів та притулків для дітей, які опинились у скрутному становищі, а також створення готелів чи будинків нічліжки для таких дітей;

- створення системних короткострокових прийомних сімей, які беруть на утримання дитину на короткий час (декілька тижнів або кілька місяців), доки біологічна сім'я дитини не вирішить своїх соціальних проблем або доки дитину не влаштують в інші форми опіки;

- ширше залучення до розв'язання проблем безпритульності та бездоглядності дітей та “дітей вулиці”, громадських, благодійних організацій, комерційних підприємств, меценатів, приватних осіб;

- розробку методичних рекомендацій щодо соціальної роботи 3 зазначеною категорією дітей;

- підтримку організацій, які займаються бездоглядним дітьми та безпритульними (Капська, 2011).

Вважаємо, що для подолання проблеми дитячої бездоглядності та безпритульності потрібно орієнтуватись на інноваційні форми соціальної роботи. Одним із ефективних шляхів $є$ вулична соціальна робота, якій відводиться дедалі вагоміша роль у подоланні бездоглядності та безпритульності. Вулична соціальна робота знайшла своє активне впровадження в Європейських країнах. Як зазначає Ноздріна, серед форм вуличної соціально-педагогічної роботи повинні бути застосовані такі як: масові заходи, ігри, вуличний театр, спортивні ігри, туристичні походи, літні табори тощо Досить популярним за останні роки є застосування у практиці соціальної роботи нових методологічних підходів, таких як техніки втручання та психологічні моделі. (Морозова, 2006; Ноздріна, 2006)

Профілактична робота має бути цілеспрямованою, постійною, комплексною. Як свідчить аналіз джерел, подолання дитячої бездоглядності і безпритульності можливе лише за умови впровадження системних заходів. Попередження, своєчасне виявлення і ефективне надання 
соціальних послуг $\epsilon$ важливими умовами подолання дитячої бездоглядності та безпритульності. Цього можна досягти шляхом активної співпраці між державними та громадськими структурами. Саме тому в роботі 3 бездоглядними дітьми необхідно використовувати якісно нові форми роботи, які дозволять ефективно вирішити проблему. Незважаючи на те, що державними органами, громадськими та благодійними організаціями, які опікуються проблемами бездоглядних та безпритульних дітей, останнім часом ведеться активна робота з усунення причин, що сприяють розповсюдженню дитячої бездоглядності та безпритульності, у цій сфері залишається безліч питань, невирішеність яких знижує ефективність діяльності суб'єктів профілактики цього явища.

\section{References}

Horobets, I.V. (2011). Prevention of child homelessness and neglect as a direction of activity of public authorities. The state. construction. №2.

Protecting children who need special attention from society. (2017). Statistical collection.

Information on the activities of the Caritas - Lviv UGCC Charitable Foundation. (2018). Restored from http://caritas-lviv.org/about/.

Kapska, A. J. (2011). Social work technologies for street children and street children. Social work: teaching Manual. Education and Science, Youth and Sports of Ukraine. K .: Word, 293-341.

Karpenko, O. (2001). Legislative provision of family forms of maintenance and upbringing of orphans and children deprived of parental care under the legislation of Ukraine. Entrepreneurship, economy and law. № 3. 58 - 60.

Makichuk, T. (2008). Legal support for social support for children who do not have proper parental care, before granting them legal status as an orphan or a child deprived of parental care. Entrepreneurship, economy and law. No. 9. 107 - 112.

Morozova, S. (2004). Legal bases of activity of guardianship and guardianship bodies. State and law. Law and Political Science: Coll. of sciences. ed / ed K .: Inst. Of State and Law. V.M. $\begin{array}{llllll}\text { Koretsky NAS } & \text { of } & \text { Ukraine. } & 333 & - & 337 .\end{array}$ Nozdrina, O. (2006). The system of state bodies for social protection of the rights of orphans and children deprived of parental care. State and law. Law and Political Science: Coll. of sciences. ed / ed K .: Inst. Of State and Law. V.M. Koretsky NAS of Ukraine. 262-271.

Main categories of children's problems in Ukraine. (2020). Restored from http://uwcfoundation.com/en/detskie-problemyi

Rogach, Z.I. (2010). Homeless and homeless street children as a problem in modern Ukrainian society. MAUP Scientific Papers. K .: 3 (26). 160-165.

\section{Список використаних джерел}

Горобець, I.B. (2011). Профілактика дитячої безпритульності та бездоглядності як напрям діяльності органів державної влади. Держ. будівництво. №2.

Захист дітей, які потребують особливої уваги суспільства. (2017). Статистичний збірник. Відновлено $з$ http://www.ukrstat.gov.ua/druk/publicat/kat u/2018/zb/07/zb zdpus 2017.pdf

Інформація про діяльність Благодійного фонду «Карітас - Львів УГКЦ». (2018). Відновлено 3 http://caritas-lviv.org/about/ .

Капська, А. Й. (2011). Технології соціальної роботи з бездоглядними та безпритульними дітьми. Соціальна робота : навч. Посібник. М-во освіти і науки, молоді та спорту України. К.: Слово, 293-341.

Карпенко, О. (2001). Законодавче забезпечення сімейних форм утримання та виховання дітей-сиріт і дітей, позбавлених батьківського піклування, за законодавством України. Підприємництво, господарство і право. № 3.58 - 60 .

Макійчук, Т. (2008). Правове забезпечення соціальної підтримки дітей, які не мають належного батьківського піклування, до надання їм юридичного статусу дитини-сироти чи дитини, позбавленої батьківського піклування. Підприємництво, господарство $i$ право. № 9. 107 - 112. 
Морозова, С. ( 2004). Правові основи діяльності органів опіки та піклування. Держава $i$ право. Юридичні і політичні науки : зб. наук. пр. / редкол. К.: Ін-т держави і права ім. В.М. Корецького НАН Украӥни. 333 - 337.

Ноздріна, О. (2006). Система державних органів соціального захисту прав дітей-сиріт та дітей, позбавлених батьківського піклування. Держава і право. Юридичні $і$ політичні науки : зб. наук. пр. / редкол. К.: Ін-т держави і права ім. В.М. Корецького НАН України. 262 - 271.

Основні категорії дитячих проблем в Україні. (2020). Відновлено 3 http://uwcfoundation.com/ua/detskie-problemyi

Рогач, 3. I. (2010). Безпритульні і бездоглядні “діти вулиці” як проблема сучасного українського суспільства. Наукові праціi МАУП. К.: Вun. 3(26). 160-165.

\section{Contact information:}

Ольга Тепла

olya.tepla.1999@gmail.com 